EUROPEAN THYROID ASSOCIATION HENNING PRIZE LECTURE, Goteborg, 10 September 2002

\title{
Primary congenital hypothyroidism: defects in iodine pathways
}

Jan J M de Vijlder

Department of Paediatric Endocrinology, Emma Children's Hospital AMC, Academic Medical Centre, University of Amsterdam, Amsterdam, The Netherlands

(Correspondence should be addressed to Jan J M de Vijlder; j.j.devijlder@amc.uva.nl)

\begin{abstract}
The thyroid gland is the only source of thyroid hormone production. Thyroid hormone is essential for growth and development, and is of special importance for the development of the central nervous system. It was for that reason that neonatal screening on congenital hypothyroidism was introduced and is now performed in many countries. Defects in thyroid hormone production are caused by several disorders in hormone synthesis and in the development of the thyroid gland (primary hypothyroidism) or of the pituitary gland and hypothalamus (central hypothyroidism).

This paper describes defects in the synthesis of thyroid hormone caused by disorders in the synthesis or iodination of thyroglobulin, leakage of iodinated proteins by a stimulated thyroid gland and the presence of abnormal iodoproteins, mainly iodinated albumin, in the thyroid gland and blood circulation. Circulating thyroglobulin and abnormal iodoproteins, as well as the breakdown products of these iodoproteins excreted in urine, are used for etiological diagnosis and classification. Moreover, our finding of an enzyme that catalyses the dehalogenation of iodotyrosines, which is important for iodine recycling and required for economical use of iodine, is also referred to.
\end{abstract}

European Journal of Endocrinology 149 247-256

\section{Introduction}

Thyroid hormone, exclusively produced by the thyroid gland, plays a key role in the growth and differentiation of many organs. It is of special importance for the development of the central nervous system in the pre- and postnatal period $(1,2)$. For thyroid development and for synthesis, storage and secretion of thyroid hormone a variety of transcription factors and a sequence of precisely tuned events (3) are required. Disorders in one of these factors or in the intermediate reaction steps are the molecular basis of abnormalities in thyroid development and/or in thyroid hormonogenesis that result in congenital hypothyroidism. Severe shortage of thyroid hormone after birth from several weeks on will result in serious mental and motor handicaps. The initial reports on the absence of thyroid tissue leading to sporadic cretinism and myxoedema, and the occurrence of endemic cretinism due to iodine deficiency are from the middle of the 19th century. The first descriptions of inborn errors in thyroid metabolism causing hypothyroidism with goitre are from Pendred (4) and Osler (5) at the end of the 19th century. Nevertheless, even in the middle of the twentieth century, many patients with congenital hypothyroidism were referred to paediatricians at school age (6).

Apart from the children with the classical type of congenital hypothyroidism, there are also special groups of children who are in danger from a shortage of thyroid hormone after birth such as preterm born infants (7) and infants with Down's syndrome (8).

During pregnancy the mother provides substantial amounts of thyroid hormone to the foetus (9), so the delay in cerebral development caused by congenital hypothyroidism $(\mathrm{CH})$ is mainly the result of postnatal thyroid hormone deficiency. The result of the maternal thyroid hormone provision to the foetus is that hypothyroid newborns do not show clear clinical signs at birth. The risk of mental retardation and the difficulty in recognising the disease were reasons for introducing neonatal mass screening programmes in many countries. The introduction was attended by a considerable increase in the apparent overall incidence of $\mathrm{CH}$, most likely due to the recognition of mild disorders that formerly remained undetected, were detected later and/or were not recognised as congenital problems $(10,11)$.

Congenital hypothyroidism can be of thyroidal or of central (hypothalamic/pituitary) origin (Table 1), with a widely diverse molecular aetiology. Almost all screening programmes are directed towards the detection of thyroidal congenital hypothyroidism (incidence about 1:3100) (12) by measuring thyrotrophin (TSH) in filter blood spots, and they ignore central congenital hypothyroidism, which has an estimated incidence of about 1:20000 births $(12-14)$. In this 
Table 1 Congenital hypothyroidism.

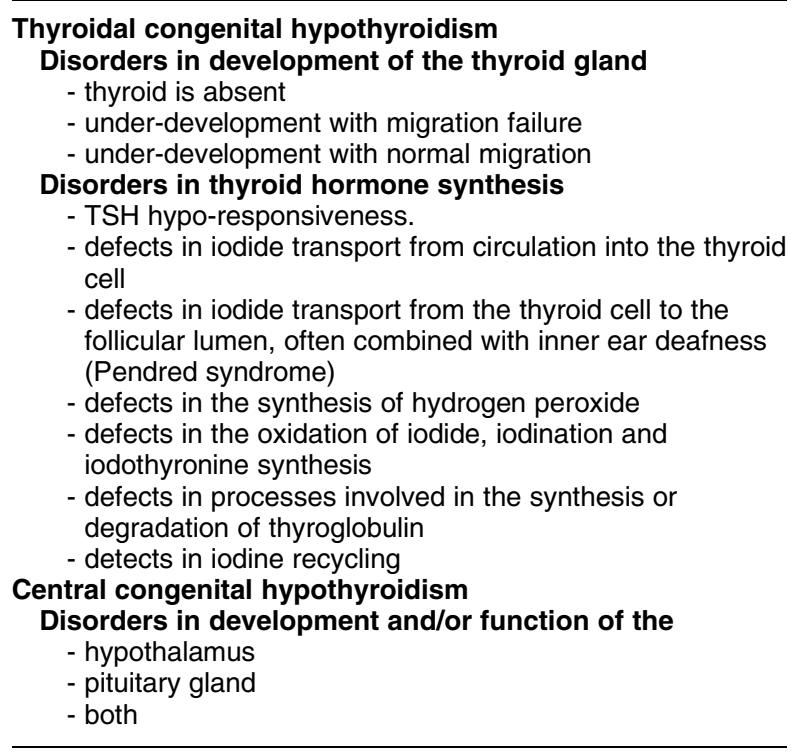

paper, I mainly describe disorders in the mechanism of thyroid hormone synthesis taking place at the apical membrane of the thyroid gland.

\section{Thyroid metabolism}

Iodination takes place at the apical membrane (see oval in Fig. 1). The active transport of iodide into the follicular cells is mediated by the $\mathrm{Na}^{+}-\mathrm{I}^{-}$symporter (NIS) as the first crucial step in thyroid hormone synthesis (for review see (15)). Iodide taken up by the thyrocytes is transported through the apical membrane by the anion transporter, pendrin (16). Recently, another apical iodide transporter protein (AIT) (17) has been described, which was identified as an NIS homologue.

The oxidation of iodide requires hydrogen peroxide that is synthesised outside the cell at the apical border catalysed by the thyroid-oxidase complex. Recently, two proteins of this complex ThOX1 and ThOX2 have been identified (18). The iodination of tyrosine residues, commonly referred to as iodide organification, is catalysed by the membrane-bound thyroperoxidase (TPO). Besides the binding of iodine to tyrosine, TPO also catalyses the coupling of iodotyrosines to iodothyronine residues in thyroglobulin (TG) under oxidative conditions. In order to deliver thyroid hormone to the blood circulation, TG is internalised by endocytosis that can take place by non-selective fluid phase uptake and by receptor-mediated processes. Two receptors playing a role in the endocytosis of TG have been identified: megalin (19) and the thyroid asialoglycoprotein (20) receptor. After endocytosis, thyroxine $\left(\mathrm{T}_{4}\right)$, triiodothyronine $\left(\mathrm{T}_{3}\right)$ and the remaining iodotyrosine residues in TG are released by lysosomal proteolysis. The iodothyronines are secreted into the circulation, non-covalently bound to plasma proteins and transported to target organs. The iodotyrosine molecules are deiodinated and the iodide can be reused as substrate for the iodinating processes in the thyroid.

In all these steps leading to the synthesis and release of thyroid hormone and the recycling of iodine, defects may occur (Table 2).

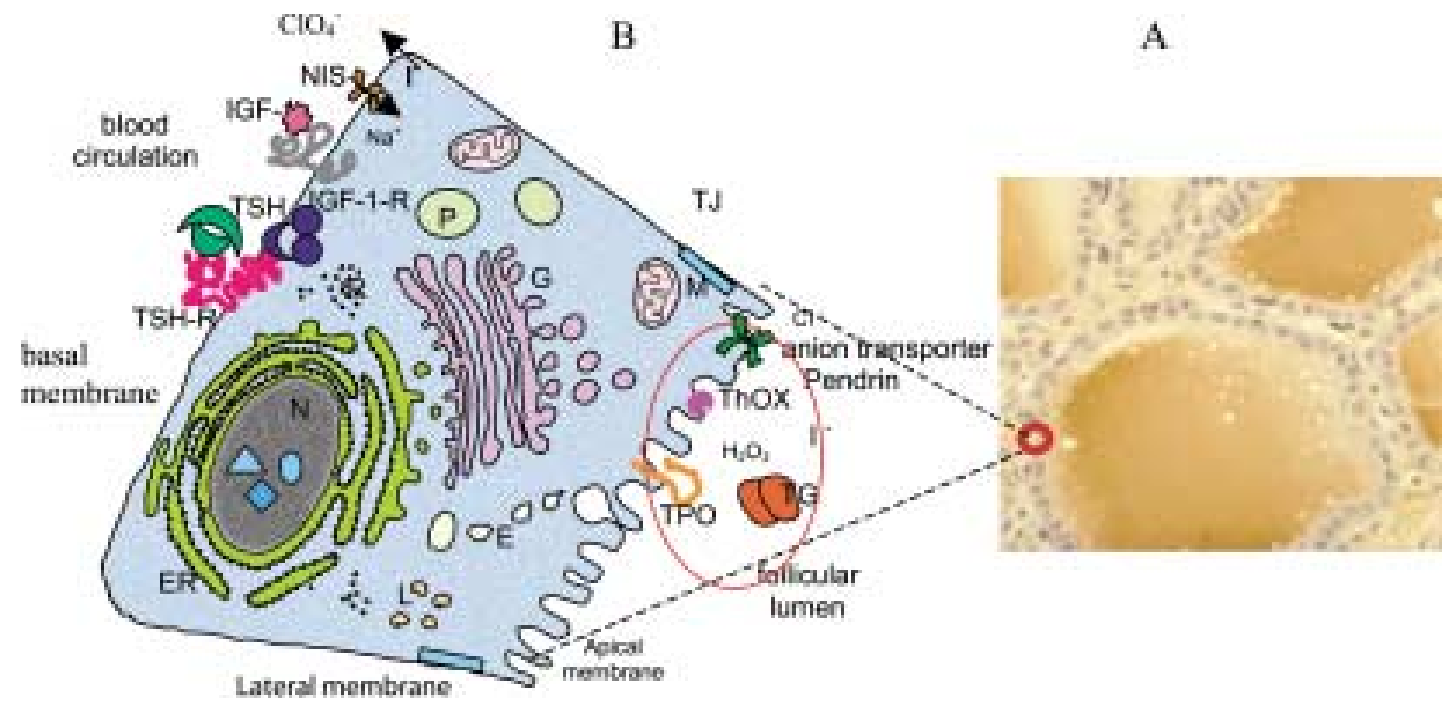

Figure 1 (A) Section of a normal thyroid gland stained with haematoxylin-eosin and immuno-stained with anti-thyroglobulin. (B) Schematic drawing of a thyroid cell with the main iodination pathways. Modified from Van de Graaf et al. (24). IGF-1, insulin-like growth factor I; IGF-1-R, IGF-I receptor; TSH-R, thyrotrophin receptor; N, nucleus; M, mitochondria; L, lysosomes; E, endosomes; TJ, tight junction. 
Table 2 Disorders in thyroid hormone synthesis.

\begin{tabular}{|c|c|c|c|c|c|}
\hline Class of defect & Features & $\begin{array}{l}\text { Plasma TSH } \\
\text { conc. }\end{array}$ & $\begin{array}{l}\text { Plasma T4 } \\
\text { conc. }\end{array}$ & ${ }^{123} I^{-}$uptake + wash-out ${ }^{\star \star \star *}$ & Putative mol. defects \\
\hline $\begin{array}{l}\text { Thyroglobulin } \\
\text { synthesis } \\
\text { defects }\end{array}$ & $\begin{array}{l}\text { Presence of iodoalbumin in plasma and/or } \\
\text { iodopeptides in urine. Plasma TG* conc. Not } \\
\text { related to TSH plasma conc. }\end{array}$ & Elevated & Low-normal & $\begin{array}{l}\text { Elevated uptake. Partial wash-out possible. } \\
\text { Rapid turnover dependent on amount of TG } \\
\text { in follicular lumen }\end{array}$ & $\begin{array}{l}\text { A: Defects in TG-synthesis pathway } \\
\text { B: Mutations in TG gene }\end{array}$ \\
\hline \multirow[t]{2}{*}{$\begin{array}{l}\text { lodide } \\
\text { transport }{ }^{\star \star}\end{array}$} & $\begin{array}{l}\text { Through basal-lateral membrane. Saliva/blood } \\
\text { ratio of iodide near unity }\end{array}$ & Elevated & Low & No uptake & Sodium-iodide symporter (NIS) \\
\hline & Through apical membrane ${ }^{\star * *}$ deafness & $\begin{array}{l}\text { Normal or } \\
\text { elevated }\end{array}$ & Low or normal & Partial wash-out & $\begin{array}{l}\text { Pendrin (PDS gene) + apical iodide } \\
\text { transporter (AIT) and/or possibly } \\
\text { other transporters? }\end{array}$ \\
\hline \multirow{3}{*}{$\begin{array}{l}\text { lodide } \\
\text { organification } \\
\text { defect }^{\star \star}\end{array}$} & Partial** (PIOD) deafness & $\begin{array}{l}\text { Normal- } \\
\text { elevated }\end{array}$ & Low-normal & Partial wash-out & \\
\hline & Partial defect (PIOD) & $\begin{array}{l}\text { Normal- } \\
\text { elevated }\end{array}$ & Low-normal & Partial wash-out & $\begin{array}{l}\text { Thyroid oxidase (ThOX2), } \\
\text { monoallelic mutation }\end{array}$ \\
\hline & Total (TIOD) & Elevated & Low & Total wash-out & ThOX2 or TPO biallelic mutations \\
\hline $\begin{array}{l}\text { lodine recycling } \\
\text { defect }\end{array}$ & Presence of mono- and di-iodotyrosines in urine & $\begin{array}{l}\text { Variable, } \\
\text { dependent on } \\
\text { iodine status }\end{array}$ & $\begin{array}{l}\text { Variable, } \\
\text { dependent on } \\
\text { iodine status }\end{array}$ & High uptake, with rapid turnover & DEHALI \\
\hline
\end{tabular}

Conc., concentration; PIOD, partial organification defect; TIOD, total organification defect.

In thyroid by dyshormonogenesis elevated plasma TSH concentrations, stimulating the thyroid gland, result in elevated plasma TG concentrations, except in the cases of TG synthesis defects and TSH receptor inactivation where elevated TSH concentrations do not give increased plasma TG concentrations.

* Pendred's syndrome is characterised by a combined thyroid defect and deafness.

** Pendred's syndrome is probably caused by an iodide transport defect over the apical membrane, radio-iodine uptake studies reflect a partial organification defect

作 an hour it is called a partial or total wash-out respectively. 


\section{Disorders in thyroid hormone synthesis}

\section{Thyroglobulin synthesis}

In the process of thyroid hormone synthesis and storage, TG plays a prominent role. TG is encoded by a large gene, mapped to human chromosome $8 \mathrm{q} 24$, spanning more than $300 \mathrm{~kb}$ (21) containing 48 exons (22). The primary structure of human TG was deduced from the sequence of its 8448-base mRNA (23). The open reading frame for human TG consists of 8307 nucleotides coding for a protein of 2768 amino acid residues which has 66 tyrosine residues and a signal peptide of 19 amino acids (24). The TG sequence contains several repeats - in the N-terminal half eleven type-1 cysteine repeats were described (25). These repeats have been reported in other proteins and may play a role in the self-folding of proteins or may act as a proteinase inhibitor (26).

The structure of TG is important for optimal $\mathrm{T}_{4}$ production. The protein-dimer (molecular mass 660000 ) consists of two identical monomers containing 10\% carbohydrates. Four to five tyrosine residues (acceptor residues) in the TG monomer, which can be preferentially iodinated (27), are considered to couple with other specific iodo-tyrosine residues (donor residues) to form iodothyronine. The sites in the TG molecule where iodothyronine residues are formed are the socalled hormonogenic sites. An important hormonogenic site is the N-terminal tyrosine residue (tyr 5; acceptor) that most likely couples with iodotyrosine 130 as donor. It can be expected that mutations causing small changes in structure already influence coupling efficiency and, as a consequence, thyroid hormone synthesis and release (28). Even amino acid changes, considered to be polymorphic, may influence the efficiency of thyroid hormone synthesis, changes that may become important under iodine deficient conditions.

\section{Thyroglobulin synthesis defects}

The characterization of TG synthesis defects is not easy to establish. The physiological characteristics leading to this classification are shown in Table 2. The concentrations of TSH and thyroid hormones as well as the iodine uptake studies are indicative but one of the parameters important for the diagnosis is the relatively low plasma TG concentration in relation to the plasma TSH level. In practice, the definition 'TG synthesis defect' is a clinical-physiological one. It does not cover defects in the gene coding for TG, but includes defects in the whole process of TG synthesis (29).

Thyroglobulin synthesis defects in animals Before studies with recombinant DNA and transgenic mice became possible, the availability of animals with inherited congenital hypothyroidism and goitre proved very useful as models for the study of disorders in TG synthesis.

Five animals with TG synthesis defects have been described, and four are elucidated at the molecular level. The Afrikander cattle (30) in which affected animals were borderline euthyroid required special care for normal growth, development and reproduction. The molecular defect appeared to be caused by a nonsense mutation (Arg697Stop) in exon 9 in the gene coding for TG. This mutation gives rise to a thyroglobulin fragment with a molecular mass of 75000 plus an alternatively spliced TG monomer (molecular mass $250000)$, missing exon 9 (31, 32).

The Australian Merino sheep (33) were severely hypothyroid and most lambs were either stillborn or died soon after birth. In the thyroid gland and blood circulation, abnormal iodinated proteins were observed, among which was iodinated albumin. In the thyroid gland no TG (molecular mass: 660000) could be found. The defect inherited in an autosomal recessive way (34).

In the $\operatorname{cog} / \mathrm{cog}$ mouse, congenital goitre is linked to the TG locus and is caused by a Leu2366Pro transition in the acetylcholesterase domain of the TG molecule (35). This mutation resulted in an endoplasmic reticulum (ER) storage disease.

Another mutation in the TG molecule that inherited in an autosomal recessive way has been found in severely hypothyroid $\mathrm{Rdw}$ rats (plasma $\mathrm{T}_{4}$ concentration: $15 \mathrm{nmol} / \mathrm{l}$; normal: $64 \mathrm{nmol} / \mathrm{l}$, TSH concentration: $9.8 \mathrm{ng} / \mathrm{ml}$; normal: $1.1 \mathrm{ng} / \mathrm{l})$. DNA sequencing revealed a Gly2320Arg mutation in the acetylcholinesterase-like domain. The molecular chaperones GRP94, GRP78 and calreticulin were accumulated in the thyroid gland of these animals. TG was not secreted into the follicular lumina, but was retained in the dilated ER (36).

The Dutch goats, a mixed strain of Saanen and dwarf goats, were severely hypothyroid. Almost all affected goats required thyroid hormone treatment or extra iodide administration to survive (37). The defect is inherited in an autosomal recessive way (38). The molecular defect in the TG gene was localised in exon 8 caused by a TAC(Tyr)/296/TAG(Stop) mutation (39). The mutation gives rise to a cys-rich N-terminal TG peptide fragment with a molecular mass of $35 \mathrm{kDa}$, and about $40 \mathrm{kDa}$ when glycosylated, as in the in vivo situation. These TG fragments are transported to the follicular lumen, conjugated by disulphide bridges to high molecular weight complexes from which the tyrosine residues can be iodinated and coupled to thyroid hormone residues when more than the normal amount of iodine was administered, rendering the animals euthyroid $(40,41)$. For the neonates, it was very beneficial to give the mothers iodide $(37,42)$.

Thyroglobulin synthesis defects in man Five mutations in the TG gene have been described in 
human pathology. A homozygous C886T transition in exon 7 results in the replacement of an Arg residue into a premature stop codon at amino acid position 277 in TG upon translation (43). Clinically, hypothyroidism, observed in three related patients, was not severe indicating that the short TG fragment was still able to produce thyroid hormone, a phenomenon that was also observed in the goat model and in in vitro experiments (44). In these experiments it was shown that the preferential coupling of iodinated tyrosine residues 5 and 130 was still present, but less pronounced than in intact TG.

In a Japanese family a deletion of 68 amino acids from the N-terminal part of thyroglobulin, due to an in-frame mutation of exon 4 was observed (45). The resulting TG molecule lacks the donor tyrosine residue 130 and a cys-containing repeated sequence characteristic for the first half of the molecule. Consequently, this patient was severely hypothyroid.

In a Brazilian family, two hypothyroid patients with large goitres were described. Investigation of these goitres revealed that in the TG gene a CGA(Arg) 1510 TGA(stop) transition gave rise to a truncated TG polypeptide of 166260 Da. Besides this mutation, an alternative splice product was present (46) that is also found in normal thyroid tissue, resulting in a TG lacking 57 amino acids.

Another family has been described in which the TG mRNA lacked $138 \mathrm{nt}$ between position 5590 and 5727. The severely hypothyroid patients, homozygous for this deletion, presented multinodular goitres. Despite high TSH levels the serum TG level was below the detection level $(<1.0 \mu \mathrm{g} / \mathrm{l})$ and no increase could be observed after TSH stimulation (47). The disease in the affected patients was associated with massive induction of specific ER molecular chaperones including the hsp90 homologue, GRP94, and the hsp70 homologue, BiP. From thyroid tissues of the four patients, light microscopy demonstrated the presence of intracellular TG despite its absence in thyroid follicle lumina, while electron microscopy indicated abnormal distension of the endoplasmic reticulum. The data suggest that these patients synthesise a mutant thyroglobulin which is defective for folding/assembly, leading to a markedly reduced ability to export the protein from the ER to the follicular lumen (48). Thus, these kindreds suffer from a thyroid ER storage disease, a cell biological defect phenotypically indistinguishable from that found in $\mathrm{cog} / \mathrm{cog}$ mice (35).

Patients containing a Cys1263Arg mutation (28) are described as having an arrest in the endoplasmic reticulum as well. These patients were mildly hypothyroid to euthyroid, indicating that in the follicular lumen sufficient TG had to be iodinated to deliver adequate amounts of thyroid hormone.

In Fig. 2, the locations of the various mutations in the TG protein molecule in man and animals are shown schematically.
From the localisation of the mutations, we get the impression that patients producing shorter TG fragments are less severely hypothyroid than the patients having mutations in the acetylcholesterase domain of TG, indicating that shorter TG fragments are secreted more easily into the follicular lumen than TG molecules with more C-terminal mutations.

The patient where exon 4 was spliced out lacks a Cyscontaining repeat and Tyr residue 130 . This patient was also severely hypothyroid. Thyroid dyshormonogenesis might be caused because the Tyr130 donor residue was missing. Otherwise the lack of a Cys-containing repeat might cause misfolding of the protein resulting in accumulation of TG in the ER and proteolysis.

\section{'Abnormal' iodinated proteins and breakdown}

products It is known that besides TG other proteins such as albumin can be iodinated. Initial reports suggested that albumin was produced by the thyroid (49). In contrast with this, RT-PCR and labelling experiments showed that albumin in the thyroid gland originates from blood (50) and is iodinated. Some of the iodinated albumin rapidly leaks out, giving a high protein bound iodine value in the blood circulation (51). Some is broken down by lysosomal enzymes in the thyroid, giving rise to the formation of iodinated peptides and iodinated histidine which are excreted in urine, providing a new criterion in the diagnosis of TG synthesis defects, even prenatally (52).

Serum albumin may be taken up by the thyroid gland either by diffusion via the tight junctions or via basolateral endocytosis (53), and is iodinated in the follicular lumen. For the release of iodo-albumin into the circulation intra- or intercellular routes are postulated. The intracellular route follows the internalisation of iodinated albumin by pinocytosis and exocytosis at the basolateral membrane. The intercellular pathway is by leakage via the tight junctions.

The immuno-histological pictures show that the inflow and outflow of protein under these pathological conditions occur mainly intercellularly (Fig. 3) and is strongly TSH dependent. In accordance with these findings we have shown that the width and number of chains of the tight junctions are inversely related to the TSH level, most likely resulting in increased protein leakage at higher TSH levels (54) (Fig. 4A, B).

\section{Iodide organification}

The oxidation and binding of iodine to tyrosine residues in TG are commonly referred to as iodide organification. Under normal conditions, the iodide uptake is the rate-limiting step in the iodination process. Iodide in the thyroid is derived from two distinct sources: iodide transported into the cell via a transporter system (NIS) (15) and iodide obtained via deiodination of organic iodine compounds within the gland. How far both iodide pools are exchangeable is a subject of 


TG mRNA WT

TG protein: WT

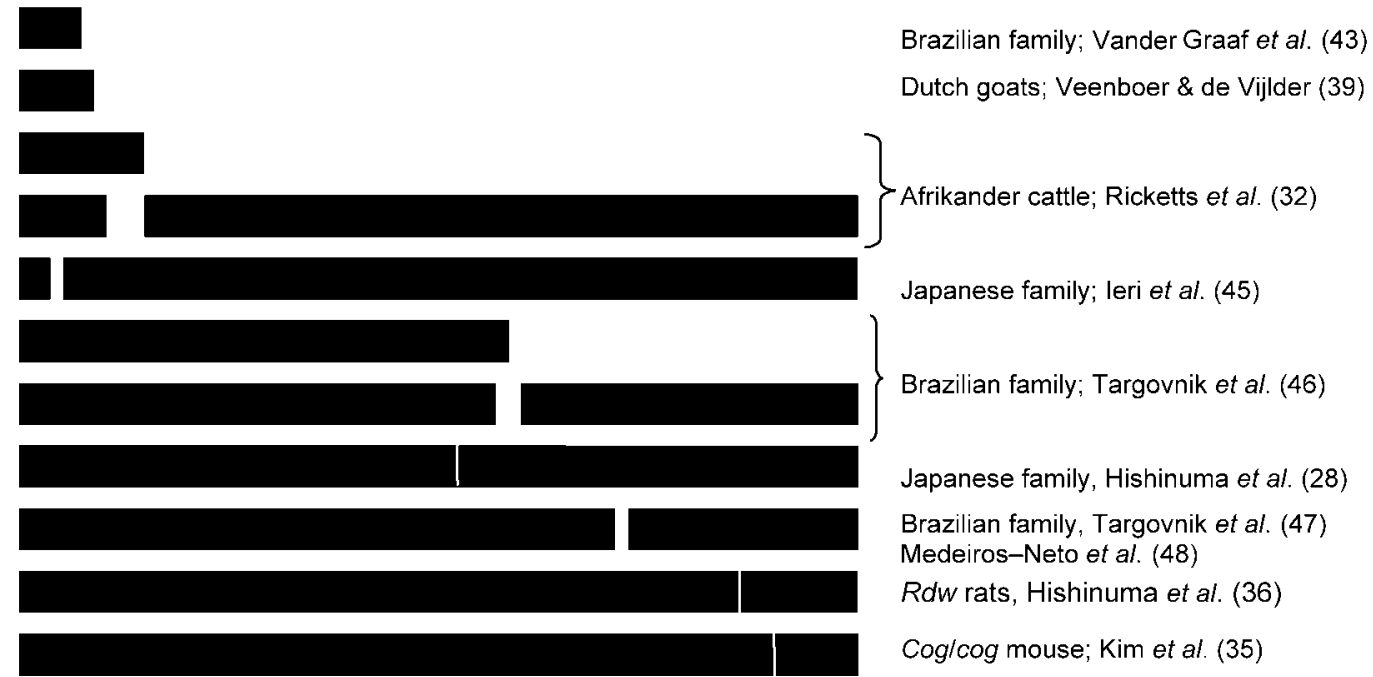

Figure 2 TG mutations in patients described in the literature, causing congenital hypothyroidism. WT, wild type; sp, signal peptide; $\uparrow$ arrow with solid tail, human pathology; $\mathbf{\uparrow}$ arrow with broken tail, animal pathology.

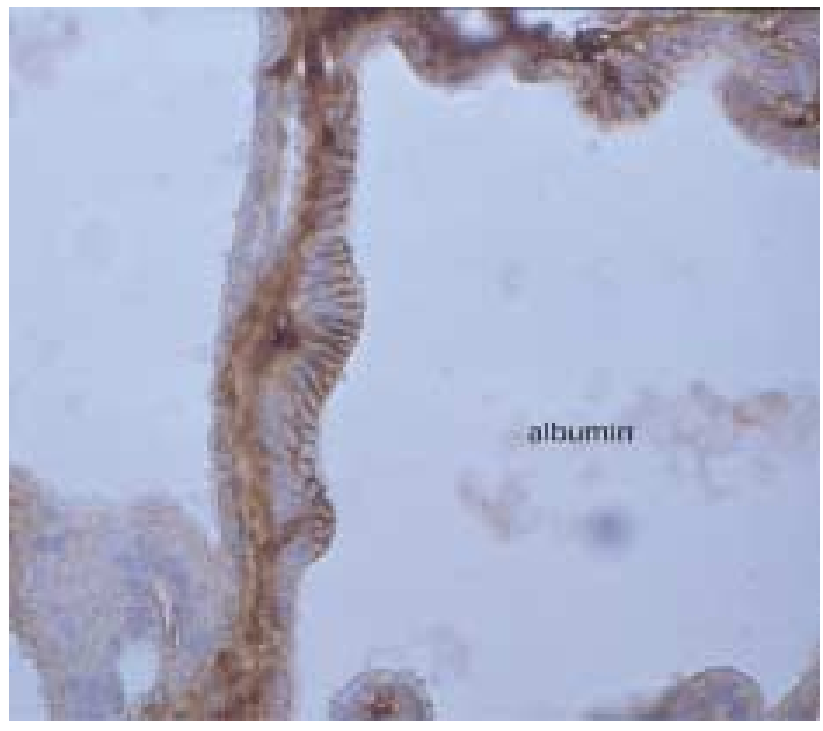

Figure 3 Immuno-histochemical picture of a follicle that contains albumin. Albumin antigens are present between the epithelial cells from the base to the top. The epithelium at the left of the septum is flat and does not show transepithelial passage of serum proteins. Small amounts of albumin antigens are present in the follicular lumen (magnification 400x). controversy. However, in view of the rapid iodination reaction, catalysed by TPO, the free intracellular iodide concentration is low especially when compared with the total amount of glandular iodine. An impression of the thyroid iodide concentration in the thyroid cells can be obtained by the inhibition of iodide uptake after administration of sodium perchlorate or sodium thiocyanate, visualized by radioiodine $\left({ }^{123} \mathrm{I}^{-}\right)$. Normally no or $<10 \%$ of the radioiodine taken up will be released (Fig. 5).

Thyroid peroxidase is $110 \mathrm{kDa}$ in size, is encoded by the TPO gene $(150 \mathrm{~kb})$ containing 17 exons, and is located on chromosome $2 \mathrm{p} 25$. The gene is exclusively expressed in the thyroid gland under the influence of the thyroid transcription factors NKX2.1 (TTF1), FKL15 (TTF2) and PAX8. The protein shows one transmembrane helix, with a large extracellular N-terminal part containing a haem group, essential for enzyme activity.

The generation of hydrogen peroxide is a critical step in thyroid hormonogenesis. The thyroid oxidase 1 (ThOX1) and 2 (ThOX2) genes have recently been identified as coding for components of the hydrogen peroxide generation system of the thyroid (55). The mRNAs coding for ThOX1 and 2 are 5369 and 6126 nucleotides, coding for proteins of 1551 and 1548 amino acids respectively. The structure of these proteins, inserted into the apical membrane, includes seven putative transmembrane domains, an NADPH 
A

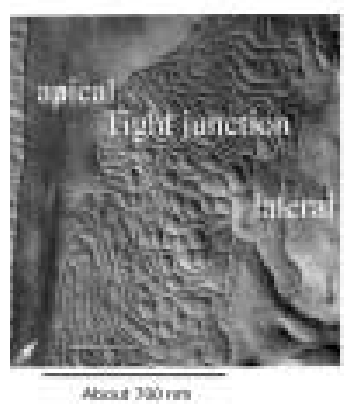

Normal TSH

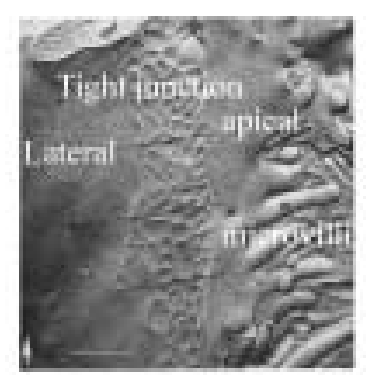

High TSH

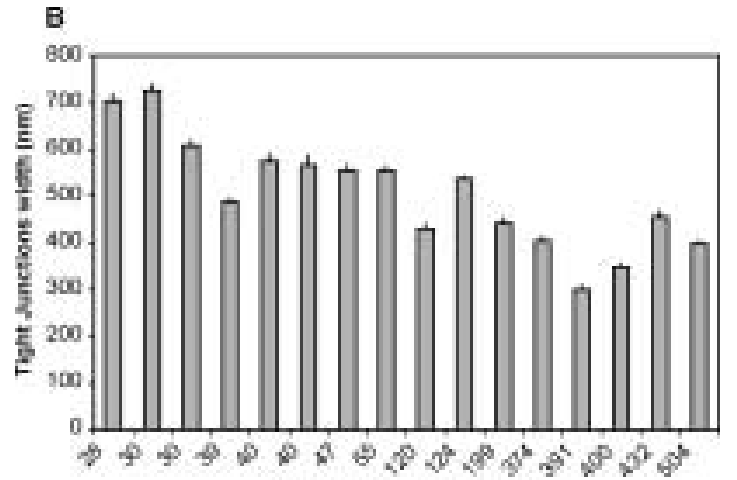

TSH concevtruisons imLin]

Figure 4 Dependence of width of tight junction on plasma TSH levels. (A) Electron microscopic pictures from freeze fracture sections from normal thyroid tissue and from goitre tissue (high TSH). (From Van Uyen et al. (54)). (B) Width of tight junctions in relation to plasma TSH values, given in $\mathrm{mU} / \mathrm{l}$. Each value is the average of about 300 measurements, the mean standard error is about $12 \mathrm{~nm}$. TSH concentrations were determined by a special goat-bovine TSH radioimmunoassay (54).

and a FAD binding site, two $\mathrm{Ca}^{2+}$ binding sites (EF hands) and haem binding sites. From reconstruction experiments, it is clear that more components have to be included in the thyroid oxidase system (56).

\section{Iodide organification defects}

Iodination defects can be partial or total. This depends on the degree to which iodide can be organified. Total organification defects (TIODs) are characterised by discharge of more than $90 \%$ of the (radio) iodide taken up by the gland within $1 \mathrm{hr}$ after i.v. administration of sodium perchlorate (Fig. 5B). Partial organification defects (PIODs) are characterised by a discharge of more than $10 \%$ of the accumulated radioiodine (Fig. 5A).
Partial iodide organification defects As iodination needs hydrogen peroxide, iodide and thyroglobulin as substrates at the outside of the apical membrane of the thyrocyte, a shortage in one of these components at the right place will give diminished iodination. A disorder in the function of pendrin may cause a diminished iodide transport over the apical membrane which results in iodide remaining in the thyrocyte. By inhibition of the inflow by perchlorate ions, a partial outflow will occur, resulting in a partial organification defect. In the case of a TG deficiency, insufficient protein may be present for the amount of iodide, occasionally resulting in a partial organification defect.

Furthermore, partial iodide organification defects may be caused by a diminished organification of
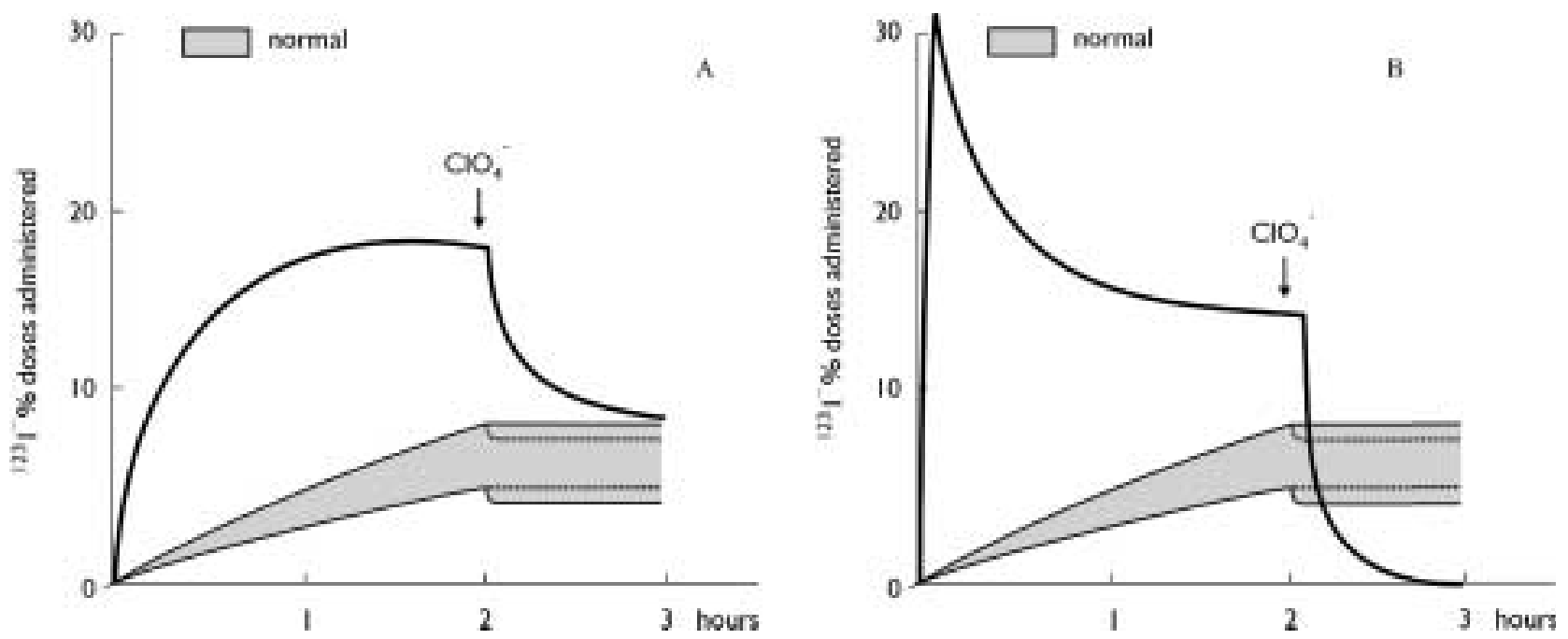

Figure 5 Radio-iodide uptake curves as observed in (A) partial iodide organification defects and (B) total iodide organification defects. The grey area represents the normal uptake curves. Inhibition of the normal iodide uptake by $\mathrm{ClO}_{4}^{-}$ions stops the uptake or causes a small decrease of $<10 \%$ of the iodide taken up. Partial iodide organification defect is defined as a wash-out of $10-90 \%$. When wash-out is $>90 \%$, the defect is defined as total iodide organification defect. 
iodide caused by disorders in thyroid peroxidase or thyroid oxidase. Recently, a partial organification defect (perchlorate discharge 76-84\%), caused by biallelic mutations in the TPO gene, has been reported. The three siblings, who were mildly hypothyroid, were found to be compound heterozygous for a missense mutation (G1687T) and a deletion in exon 10 (1808-1813del) (57). However, monoallelic mutations in the ThOX2 gene are found to cause partial organification defects, causing transient congenital hypothyroidism after birth (58). Obviously, thyroid hormone production is inadequate to fulfil the amount of thyroxine needed after birth and is most likely caused by too low a production of hydrogen peroxide. The regulation mechanism is not yet known.

Total iodide organification defects Patients with severe congenital hypothyroidism, showing a total discharge $(>90 \%)$ of radio-iodine taken up by the thyroid after administration of sodium perchlorate within $1 \mathrm{hr}$, are classified under the category of total organification defect. Missense, nonsense, splice defects and frame shift mutations have been described by several groups $(59,60)$. From a Dutch study in 45 patients from 35 families the molecular diagnosis was made (Table 3). The mutations found are: frameshift mutations (six different ones) which occur most frequently: 39 of the 69 studied TPO alleles i.e. 57\%, missense mutations (six different ones) found in 15 mutated alleles $(22 \%)$, followed by mutations that putatively affect splicing (three different ones) responsible for five affected alleles $(7 \%)$ and finally one nonsense mutation that affects four TPO alleles (6\%). The most frequently occurring single mutation is the GGCC duplication in exon 8 (61), at nucleotide position 1227 , detected in $36 \%$ of the investigated TPO alleles. This mutation has been found in $51 \%$ of the Dutch TIOD families, either in a homozygous or in a compound heterozygous fashion. In one patient with severe congenital hypothyroidism and a classical total organification defect, a homozygous deletion $(\Delta \mathrm{T} 2512$; codon 808$)$ in exon 14 was identified. The homozygosity in the patient was due to partial isodisomy of the short arm of chromosome 2 carrying a defective TPO gene (Table 3). The patient, who was born small for gestational age, was healthy

Table 3 Hereditary character of molecular defects in total iodide organification defects. Total number of families studied was 35 .

\begin{tabular}{lc}
\hline Hereditary character & No. of families \\
\hline Homozygous for a mutation in TPO & 13 \\
Compound heterozygous for mutations in TPO & 16 \\
Isodisomy (chromosome 2p) & 1 \\
Mutation in 1 allele of the TPO gene & $4^{\star}$ \\
No mutations found in the cDNA coding for TPO & 1 \\
\hline
\end{tabular}

* Mutations in promoter regions or intron sequences remain possible. with normal growth and development while being treated with thyroxine. He has a normal phenotype except for a unilateral preauricular skin tag. This shows that partial maternal isodisomy (2pter-2p12) is compatible with no or a minimal influence on normal development (62).

In one patient showing severe congenital hypothyroidism characterised by a total organification defect, no mutations were found in the gene coding for thyroid peroxidase (Table 3 ). In this case we found a bi-allelic mutation in the ThOX2 gene. These findings prove that the ThOX2 enzymatic activity is essential for thyroidal hydrogen peroxide generation and that transient congenital hypothyroidism can be genetically determined (58). From the results obtained, it is clear that total organification defects show an autosomal recessive inheritance pattern with an incidence of about 1:60 000 births mainly caused by defects in the TPO gene.

Defects in recycling of iodine TG, internalised by (micro) pinocytosis from the follicular lumen, has been found to be present in the early and late endosomes. In these organelles, containing proteolytic enzymes, thyroid hormones are freed. The hydrolysate contains amino acids, including mono- and diiodotyrosine (MIT and DIT respectively). Subsequently, MIT and DIT are deiodinated by a specific dehalogenase found not only in the thyroid but also in some peripheral organs (63).

Recently, the identification of a gene called DEHAL1 from a thyroid SAGE library based on expression in thyroid, liver, kidney and mammary gland has been reported by our group (64). The main open reading frame encodes a novel human enzyme with a conserved nitroreductase domain that is FMN dependent and catalyses the dehalogenation of iodotyrosines. It is the first cloned vertebrate dehalogenase, providing the molecular basis for an evolutionary conserved mechanism for iodine recycling.

\section{Conclusion}

In recent years much progress has been made in the clarification of thyroid defects at the molecular level, especially in the field of thyroid dyshormonogenesis. It might give the impression that most of the inherited defects in thyroid dyshormonogenesis have been elucidated. However, in a large number of patients the thyroid defect cannot be diagnosed at the molecular level. Moreover, results of thyroid SAGE analyses (65) show that about $70 \%$ of the expressed transcripts could not be linked to known genes. From this, it is clear that there is still much to be investigated in order to elucidate the mechanism of thyroid hormonogenesis and its associated disorders. 


\section{Acknowledgements}

I wish to thank all members of the department of Paediatric Endocrinology for their contribution to these investigations. I thank the groups of Vassart/Dumont (Université Libre, Brussels), Grüters/Krude (Humbold University, Berlin), Van Dijk (Veterinary Pathology, Utrecht University) and Visser (Erasmus University, Rotterdam); in the Academic Medical Centre, Amsterdam I thank the departments of Endocrinology and Metabolism (Wiersinga), Neurobiology (Baas) and Immunology (Roos) for their collaboration. The Ludgardine Bouwman Foundation and the Netherlands Organisation for Health, Research and Development are acknowledged for their support.

\section{References}

1 Morreale de Escobar G, Obregon MJ \& Escobar del Rey F. Is neurophysiological development related to maternal hypothyroidism or to maternal hypothyroxinemia? Journal of Clinical Endocrinology and Metabolism 200083 3975-3987.

2 Lavado-Autric R, Auso E, Garcia-Velasco JN, Arufe Mdel C, Escobar del Rey F, Berbel P \& Morreale de Escobar G. Early maternal hypothyroxinaemia alters histogenesis and cerebral cortex cytoarchitecture of the progeny. Journal of Clinical Investigation $20031111073-1082$.

3 Vassart G, Dumont J \& Refetoff S. Thyroid disorders. In The Metabolic and Molecular Bases of Inherited Disease, edition 7, pp 2883-2926. Eds CR Scriver, AL Beaudet, WS Sly \& D Valle. New York: McGraw Hill, 1995.

4 Pendred V. Deaf mutism and goitre. Lancet 18962532.

5 Osler W. Sporadic cretinism in America. Trans Congress of American Physicians Surgery $18964169-206$.

6 Gons MH. 1981 Urinary excretion of iodohistidine and dyshormonogenesis of the thyroid gland. PhD Thesis University of Amsterdam.

7 Van Wassenaer AG, Kok JH, De Vijlder JJM, Briët JM, Smit BJ. Tamminga P et al. Effects of thyroxine supplementation on neurologic development in infants born at less than 30 weeks' gestation. New England Journal of Medicine 1997336 21-26.

8 Van Trotsenburg ASP, Vulsma T, Van Santen HM, Cheung W \& De Vijlder JJM. Down syndrome newborns are mildly hypothyroid. Journal of Clinical Endocrinology and Metabolism $2003 \mathbf{8 8}$ $1512-1515$

9 Vulsma T, Gons MH \& de Vijlder JJM. Maternal-fetal transfer of thyroxine in congenial hypothyroidism due to a total organification defect or thyroid agenesis. New England Journal of Medicine 1989 $32113-16$.

10 De Jonge GA. Congenital hypothyroidism in the Netherlands. Lancet 19762143.

11 Alm J, Larsson A \& Zetterström R. Congenital hypothyroidism in Sweden. Incidence and age at diagnosis. Acta Pediatrica Scandinavia $1978671-3$.

12 Vulsma T \& De Vijlder JJM. Thyroid disease in newborns, infants and children. In Oxford Textbook of Endocrinology and Diabetes, pp 532-544. Eds JAH Wass \& SM Shalet. Oxford: Oxford University Press, 2000.

13 Vulsma T, Delemarre HA, de Muinck Keizer SMPF, Wiedijk BM, Gons MH, Verkerk PH et al. Detection and classification of congenital thyrotropin deficiency in the Netherlands. In The Thyroid Gland, Environment and Autoimmunity, pp 343-346. Eds HA Drexhage, JJM De Vijlder \& WM Wiersinga. Amsterdam: Elsevier Science, 1990.

14 LaFranchi SH, Hanna CE, Krainz PL, Skeels MR, Miyahira RS, Sesser DE et al. Screening for congenital hypothyroidism with specimen collection at two time periods: Results of the northwest regional screening program. Pediatrics 198576 734-740.

15 Dohan O, De la Vieja A, Paroder V, Riedel C, Artani M, Reed M et al. The sodium/iodide symporter (NIS): characterization, regulation and medical significance. Endocrine Reviews 200324 48-77.

16 Yoshida A, Taniguchi S, Hisatome I, Royaux IE, Green ED, Kohn LD \& Suzuki K. Pendrin is an iodide-specific apical porter responsible for iodide efflux from thyroid cells. Journal of Clinical Endocrinology and Metabolism 200287 3356-3361.

17 Rodriguez A-M, Perron B \& LaCroix L. Identification and characterization of a putative human iodide transporter located at the apical membrane of thyrocytes. Journal of Endocrinogy and Metabolism 200287 3500-3503.

18 DeDeken X, Wang D, Many M-C, Costagliola S, Libert F, Vassart G, et al. Cloning of two human thyroid cDNAs encoding new members of the NADPH oxidase family. Journal of Biological Chemistry 2002 $7523227-23233$.

19 Zheng G, Marino M, Zhao J \& McCluskey RT. Megalin (g330): a putative endocytic receptor for thyroglobulin. Endocrinology $19981391462-1465$.

20 Ulianich L, Suzuki K, Mori A, Nakazato M, Pietrarelli M, Goldsmith $\mathrm{P}$ et al. Follicular thyroglobulin (TG) suppression of thyroidrestricted genes involves the apical membrane sialoglycoprotein receptor and TG phosphorylation. Journal of Biological Chemistry $199927425099-25107$.

21 Baas F, Van Ommen G-JB, Bikker H, Arnberg AC \& De Vijlder JJM. The human thyroglobulin gene is over $300 \mathrm{~kb}$ long and contains introns of up to $64 \mathrm{~kb}$. Nucleic Acids Research 1986 $145171-5186$.

22 Mendive FM, Rivolta CM, Vassart G \& Targovnik HM. Genomic organization of the $3^{\prime}$ region of the human thyroglobulin gene. Thyroid 19999 903-912.

23 Malthiery Y \& Lissitzky S. Primary structure of human thyroglobulin deduced from the sequence of its 8448-base complementary DNA. European Journal of Biochemistry 1987 $165491-498$.

24 Van de Graaf SAR, Ris-Stalpers C, Pauws E, Mendive FM, Targovnik HM \& De Vijlder JJM. Up to date with human thyroglobulin. Journal of Endocrinology $2001170307-321$.

25 Mercken L, Simons MJ, DeMartynoff G, Swillens S \& Vassart G. Presence of hormonogenic and repetitive domains in the first 930 amino acids of bovine thyroglobulin as deduced from the cDNA sequence. European Journal of Biological Chemistry 1985 $14759-64$.

26 Lenarcic B \& Bevec T. Thyropins - new structurally related proteinase inhibitors. Biological Chemistry 1998379 105-111.

27 Xiao S, Dorris ML, Rawitch AR \& Taurog A. Selectivity in tyrosyl iodination sites in human thyroglobulin. Archives of Biochemistry and Biophysics $1996334284-294$.

28 Hishinuma A, Takamatsu J, Ohyama Y, Yokozawa T, Kanno Y, Kuma K et al. Two novel cysteine substitutions (C1263R and C1995S) of thyroglobulin cause a defect in intracellular transport of thyroglobulin in patients with congenital goiter and the variant type of adenomatous goiter. Journal of Clinical Endocrinology and Metabolism $1999 \mathbf{8 4} 1438-1444$.

29 Van de Graaf SAR, Cammenga M, Ponne NJ, Veenboer GJM, Gons $\mathrm{MH}$, Orgiazzi $\mathrm{J}$ et al. The screening for mutations in the thyroglobulin cDNA from six patients with congenital hypothyroidism. Biochemie 199981 425-432.

30 Van Zijl A, Schulz K, Wilson B \& Pansegrouw D. Thyroidal iodine and enzymatic defects in cattle with congenital goiter. Endocrinology 196576 353-361.

31 Tassi VPN, DiLauro R, Van Jaarsveld P \& Alvino CG. Two abnormal thyroglobulin-like polypeptides are produced from Afrikander cattle congenital goiter mRNA. Journal of Biological Chemistry $198425910507-10510$.

32 Ricketts MH, Simons MJ, Parma J, Mercken L, Dong O \& Vassart G. A nonsense mutation causes hereditary goitre in the Afrikander cattle and unmasks alternative splicing of thyroglobulin transcripts. PNAS 198784 3181-3184. 
33 Falconer IR. Biochemical defect causing congenital goiter in sheep. Nature $1965 \mathbf{2 0 5}$ 978-980.

34 Mayo GME \& Mulhearn CJ. Inheritance of congenital goitre due to a thyroid defect in merino sheep. Australian Journal of Agricultural Research 196920 533-547.

35 Kim PS, Hossain SA, Park Y-N, Lee I, Yoo S-E \& Arvan P. A single amino acid change in the acetylcholesterase-like domain of thyroglobulin causes congenital goiter with hypothyroidism in the $\mathrm{cog} / \mathrm{cog}$ mouse; a model of human endoplasmic reticulum storage diseases. Cell Biology 199895 9909-9913.

36 Hishinuma A, Furudate S-I, Oh-Ishi M, Nagakubo N, Namatame T \& Ieiri T. A novel missense mutation (G2320R) in thyroglobulin causes hypothyroidism in $r d w$ rats. Endocrinology $2001 \mathbf{4 1}$ 4050-4055.

37 Van Dijk JE. Congenital goitre in Dutch goats; a pathological characterization and an investigation of the origin of abnormal iodoproteins PhD Thesis Utrecht University, Elinkwijk BV, Utrecht, 1991.

38 Kok K, van Dijk JE, Sterk A, Baas F, Van Ommen GJB \& De Vijlder JJM. Autosomal recessive inheritance of congenital goiter in Dutch goats. Journal of Heredity $1987 \mathbf{7 8} 298-300$.

39 Veenboer GJM \& De Vijlder JJM. Molecular basis of the thyroglobulin synthesis defect in Dutch goats. Endocrinology 1993132 377-381.

40 Sterk A, Van Dijk JE, Veenboer GJM, Moorman AFM \& De Vijlder JJM. Normal-sized thyroglobulin messenger ribonucleic acid in Dutch goats with a thyroglobulin synthesis defect is translated into a 35000 molecular weight $\mathrm{N}$ terminal fragment. Endocrinology $1989124477-483$.

41 Van Voorthuizen WF, De Vijlder JJM, Van Dijk JE, Jorna TJ \& Tegelaers WHH. Euthyroidism via iodide supplementation in hereditary congenital goiter with thyroglobulin deficiency. Endocrinology $1978 \mathbf{1 0 3} 2105-2111$.

42 Piosik PA, Van Groeningen M, Baas F \& De Vijlder JJM. Effects of maternal thyroid status on fetal development in congenitally hypothyroid goats. Endocrinology 1997138 5-11.

43 Van de Graaf SAR, Ris-Stalpers C, Veenboer GJM, Cammenga M, Santos C, Targovnik HM et al. A premature stopcodon in thyroglobulin mRNA results in familial goiter and moderate hypothyroidism. Journal of Clinical Endocrinology and Metabolism 199984 2537-2542.

44 Den Hartog MT, Sijmons CC, Bakker O, Ris-Stalpers C \& De Vijlder JJM. Importance of the content and localization of tyrosine residues for thyroxine formation within the N-terminal part of human thyroglobulin. European Journal of Endocrinology 1995 $132611-617$.

45 Ieri T, Cochaux P, Targovnik H, Suzuki M, Shimoda S-I, Perret J \& Vassart G. A $3^{\prime}$ splice site mutation in the thyroglobulin gene responsible for congenital goiter with hypothyroidism. Journal of Clinical Investigation $1991 \mathbf{8 8} 1901-1905$.

46 Targovnik HM, Medeiros-Meto G, Varela V, Cochaux P, Wajchenberg BL \& Vassart G. A nonsense mutation causes human hereditary goiter with preferential production of a 171 nucleotide deleted thyroglobulin RNA messenger. Journal of Clinical Endocrinology and Metabolism 199377 210-215.

47 Targovnik HM, Vono J, Billerbeck AEC, Cerrone GE, Varela V, Mendive F et al. A 138-nucleotide deletion in the thyroglobulin ribonucleic acid messenger in a congenital goiter with defective thyroglobulin synthesis. Journal of Clinical Endocrinology and Metabolism 199580 3356-3360.

48 Medeiros-Neto G, Kim PS, Yoo SE, Vono J, Targovnik HM, Camargo $\mathrm{R}$ et al. Congenital hypothyroid goiter with deficient thyroglobulin. Identification of an endoplasmic reticulum storage disease with induction of molecular chaperones. Journal of Clinical Investigation $1996152838-2844$.

49 Jonckheer MH \& Karcher DM. Thyroid albumin. I. Isolation and characterization. Journal of Clinical Endocrinology and Metabolism $1971327-17$.
50 De Vijlder JJM, Veenboer GJM \& Van Dijk JE. Thyroid albumin originates from blood. Endocrinology $1992131578-584$.

51 Rijnberk A, De Vijlder JJM, Van Dijk JE, Jorna TJ \& Tegelaers WHH. Congenital defect in iodothyronine synthesis. Clinical aspects of iodine metabolism in goats with congenital goitre and hypothyroidism. British Veterinary Journal 1977133 495-503.

52 Kok K, Van Dijk JE, Fokkens R, Gons MH \& De Vijlder JJM. Prenatal diagnosis of a thyroglobulin synthesis defect in goats. Acta Endocrinologica $198511083-89$

53 Gire V, Kostrouch Z, Bernier-Valentin F, Rabilloud R, Munari-Silem Y \& Rousset B. Endocytosis of albumin and thyroglobulin at the basolateral membrane of thyrocytes organized in follicles. Endocrinology $1996137522-532$.

54 Van Uyen AJ, Van Dijk JE, Koch CAM \& De Vijlder JJM. Freeze fracture morphology of thyroid tight junctions in goats with different thyrotropin stimulation. Endocrinology $1985 \quad \mathbf{1 6}$ $114-118$.

55 DeDeken X, Wang D, Many MC, Costagliola S, Libert F, Vassart G et al. Cloning of two human thyroid cDNAs encoding new members of the NADPH oxidase family. Journal of Biological Chemistry $200027523227-23233$.

56 DeDeken X. Wang D, Dumont J \& Miot F. Characterization of ThOX proteins as components of the thyroid $\mathrm{H}_{2} \mathrm{O}_{2}$-generating system. Experimental Cell Research 2002273 187-196.

57 Kotani T, Umeki K, Kawano JI, Hishinuma A, Ieri T \& Harada S. Partial iodide organification defect cause by a novel mutation of the thyroid peroxidase gene in three siblings. Clinical Endocrinology 200359 198-206.

58 Moreno JC, Bikker H, Kempers MJE, Van Trotsenburg ASP, Baas F, De Vijlder JJM \& Ris-Stalpers C. Inactivating mutations in the gene for thyroid oxidase 2 (THOX2) and congenital hypothyroidism. New England Journal of Medicine 2002 347 95-102.

59 Ambrugger P, Stoeva1 I, Biebermann H, Torresani T, Leitner C \& Grüters A. Novel mutations of the thyroid peroxidase gene in patients with permanent congenital hypothyroidism. European Journal of Endocrinology 2001145 19-24.

60 Umeki K, Kotani T, Kawano J, Suganuma T, Yamamoto I, Aratake Y et al. Two novel missense mutations in the thyroid peroxidase gene, R665W and G771R, result in a localization defect and cause congenital hypothyroidism. European Journal of Endocrinology 2002146 491-498.

61 Abramowicz MJ, Targovnik HM, Varela V, Cocheaux P, Krawiec L, Pisarev MA et al. Identification of a mutation in the coding sequence of human thyroid peroxidase gene causing congenital goiter. Journal of Clinical Investigation 199290 1200-1204.

62 Bakker B, Bikker H, Hennekam RCM, Lommen EJP, Schipper MGJ, Vulsma T \& De Vijlder JJM. Maternal isodisomy for chromosome $2 \mathrm{p}$ causing severe congenital hypothyroidism. Journal of Clinical Endocrinology and Metabolism 200186 1164-1168.

63 Choufour JC, Kassenaar AAH \& Querido A. The syndrome of congenital hypothyroidism with defective dehalogenation of iodotyrosines. Further observations and a discussion of the pathophysiology. Journal of Clinical Endocrinology and Metabolism 196020 983-989.

64 Moreno JC, Keijser R, Aarraas S, De Vijlder JJM \& Ris-Stalpers C. Cloning and characterization of a novel thyroidal gene encoding proteins with a conserved nitroreductase domain. Journal of Endocrinological Investigation 20022523 (abstract).

65 Pauws E, Moreno JC, Tijssen M, Baas F, De Vijlder JJM \& Ris-Stalpers C. Serial analysis of gene expression as a tool to assess the human thyroid expression profile and to identify novel thyroidal genes. Journal of Clinical Endocrinology and Metabolism $2000 \mathbf{8 5}$ 1923-1927.

Received 5 May 2003

Accepted 12 May 2003 